\title{
ALTERNATIVE VISIONS OF CRIME AND COMMUNITY IN WILKIE COLLINS' THE WOMAN IN WHITE AND THE MOONSTONE
}

\author{
by
}

Sarah Pennington

Bachelor of Arts in English, University of Ottawa, 2019

\author{
A Major Research Paper \\ presented to Ryerson University \\ in partial fulfillment of the \\ requirements for the degree of \\ Master of Arts \\ in Literatures of Modernity
}

Toronto, Ontario, Canada, 2020

CSarah Pennington, 2020 


\section{AUTHOR'S DECLARATION FOR}

\section{ELECTRONIC SUBMISSION OF A MAJOR RESEARCH PAPER}

I hereby declare that I am the sole author of this MRP. This is a true copy of the MRP, including any required final revisions.

I authorize Ryerson University to lend this MRP to other institutions or individuals for the purpose of scholarly research. I further authorize Ryerson University to reproduce this MRP by photocopying or by other means, in total or in part, at the request of other institutions or individuals for the purpose of scholarly research.

I understand that my MRP may be made electronically available to the public. 
When T. S. Eliot described Wilkie Collins' The Moonstone (1868) as the "first and greatest of English detective novels" (413), he could not have predicted the number of writers who would take issue with his brief phrase. While some have embraced Eliot's adjectives (Bisla; Hennelly), others have critiqued the "first" and "greatest" descriptors, identifying Collins' predecessors (Duncan; Klimaszewski), and contemporaries who offer The Moonstone some competition for the title of "greatest" (Smillie; Thomas). Still others have taken issue with defining the novel as "English," due to its anti-Imperialist critiques (Narayan; Roy). Following in the footsteps of scholars such as Tamar Heller and D. A. Miller, the descriptor I choose to trouble in this essay is "detective." Though The Moonstone inarguably contains a detective character, and a complex mystery that is indeed solved through detection, I argue that, especially when viewed in conjunction with Collins' earlier novel The Woman in White (1859), Collins should be understood not as establishing the conventions of the detective novel to come, but as working against the tide of a developing genre which became increasingly police- and law-focused. Rather than valorizing the police detective or reifying the justness of the legal system, these novels articulate a vision of crime and justice outside of the boundaries of law and policing, one markedly different from the "detective" genre Eliot credits Collins with founding.

For much of its existence, justice in the detective novel has been synonymous with legal justice. Collins' most significant predecessors in the genre, Daniel Defoe and Henry Fielding, had direct experience with the English judicial system (Bradford 3), which was reflected in their works' focus on legal proceedings. Many Victorian writers, including Collins himself, were likewise inspired by the true crime tales that dominated popular newspapers and magazines at the time (Flanders). With few exceptions, fictionalized criminals face legal consequences from police or police-adjacent detective figures, ranging from Bleak House's Inspector Bucket to the 
faceless Scotland Yard officers who round up the criminals at the end of a Sherlock Holmes story (Shpayer-Makov). In The Woman in White and The Moonstone, contrastingly, the criminals are never arrested or imprisoned, and instead face extralegal forms of justice. The relationship between true crime and detective fiction in the Victorian era was a reciprocal one; not only did accounts of true crime inspire fiction, but several scholars identify the correlation between the creation of fictional police detectives and the rise of modern policing (Strahan; Flanders). John Scaggs describes the way that the valorization of the fictional police detective works in tandem with the actual police officer, writing that "the police procedural works on its audience [...] by foregrounding the police and wider judiciary system, and in doing so, the procedural becomes, over the course of its development, one of the most effective means of policing a society not governed by morality, but by fear of scandal, fear of punishment" (86). In an era where the prevalence of the police detective was increasing in both real-life England through Peelian reforms $^{1}$, and fictional England, through detective fiction, Collins critiques the figure of the police detective in order to focus on a world in which the community, rather than the state, is the source of justice and resolution.

Collins' most radical critique of the English criminal justice system comes from the mouth of the villain of The Woman in White, Count Fosco.

"The machinery [society] has set up for the detection of crime is miserably ineffective [...]

Crimes cause their own detection, do they? And murder will out (another moral epigram), will it? Ask Coroners who sit at inquests in large towns if that is true, Lady Glyde. Ask secretaries of life-assurance companies, if that is true, Miss Halcolmbe. Read your own

\footnotetext{
${ }^{1}$ In the early $19^{\text {th }}$ century, British Home Secretary Sir Robert Peel, through police reforms, worked to create a centralized and formalized police force. Among other aims, his reforms worked to create a militarydisciplinary framework for the Metropolitan police and reorient policing toward more proactive styles of poling, such as prevention (Kocak 18-19).
} 
public journals. In the few cases that get into the newspapers, are there not instances of slain bodies never found, and no murderers ever discovered? Multiply the cases that are reported by the cases that are not reported, and the bodies that are found by the bodies that are not found; and what conclusion do you come to? This. That there are foolish criminals who are discovered, and wise criminals who escape. The hiding of a crime, or the detection of a crime, what is it? A trial of skill between the police on one side, and the individual on the other." (256-257)

Fosco's impassioned speech identifies several valid faults in the English legal system. As he states, some crimes are never solved, many are never reported, and the legal system is often unable to bring the culprit to justice. However, while Fosco lays the blame at the feet of police detectives who are not as ingenious as the criminals they are attempting to catch, I argue that in The Woman in White and The Moonstone, Collins identifies a different source of blame: the English criminal justice system itself. In The Woman in White, unjust marriage laws are blamed for the villainy the victim, Laura Fairlie, faces, and the legal system is criticized as the "preengaged servant of the long purse" (1). In The Moonstone, not only are interventions by police and the law shown to be ineffective in apprehending the Moonstone's thief, but Collins critiques the origins of the gemstone's presence in England altogether, holding Britain accountable for its entirely legal Imperial thievery. In both novels, crime is not solved through police investigation or legal sanctions, but through community cooperation. Police detectives give way for amateur investigators, the evidence-giving of court trials is instead expressed through the gathering of personal narratives, and the typical consequences of prison and punishment are replaced by the expelling of the criminal from the community and extrajudicial executions. In this way, Collins 
not only critiques the flaws in English systems governing crime and punishment, but also articulates a way to solve crimes and obtain justice outside of these systems.

\section{The Failures of the Law}

Scholarship has previously identified the peculiar way in which Collins seems, at first, to follow the expected narrative of the detective figure in The Moonstone, then abandons these conventions partway through. As Miller writes, though the novel seems to initially follow the established norms of detective fiction by bringing in Sergeant Cuff to solve the mystery, "the text abandons the scenario it has so conscientiously set up" (155). This results in a reversal of the reader's expectations, "a conspicuous modification of what had seemed to be [the novel's] program" (156). While Miller's analysis focuses on the figure of the detective, I argue that Collins examines several other aspects of the criminal justice system in both The Moonstone and The Woman in White to critique them and offer extra-judicial alternatives. There are several places in Collins' novels where the police and criminal justice system fail victims of crime, forcing victims and their allies to seek recourse through other means. In many ways, The Woman in White functions as a critique of the failures of the legal system for disadvantaged populations, such as women and the working classes.

Collins explicitly outlines the way the English legal system tends to favour the wealthy over the working classes. The novel opens with Hartright's indictment of the "Law," which he claims is "the pre-engaged servant of the long purse" (1). This is illustrated in his interaction with the Fairlie family lawyer, Mr. Kyrle. He tells him that he has managed to save up a few hundred pounds, which Kyrle does not believe will be enough to pay the necessary legal expenses: "if you are right about Sir Percival Glyde and Count Fosco [ . . . every imaginable difficulty would be thrown in the way of your getting fresh evidence. Every obstacle of litigation 
would be raised; every point in the case would be systematically contested - and by the time we had spent our thousands, instead of our hundreds, the final result would, in all probability, be against us" (494). Through Kyrle, Collins critiques the costliness of the British legal system, wherein innocent people must pay vast sums of money for only a slim chance to obtain justice. Significantly, these failures of the legal system lead Hartright to seek justice through his own means: "the poverty which has denied us all hope of assistance, has been the indirect means of our success, by forcing me to act for myself. If we had been rich enough to find legal help, what would have been the result? [. . . The law would never have obtained me my interview with Mrs. Catherick. The law would never have made Pesca the means of forcing a confession from the Count" (695). Because he is unable to obtain justice through the legal system, Hartright must turn to his community for their aid in solving the mystery of Fosco's fraud and pursue justice extrajudicially.

Collins is also critical of laws surrounding marriage and women's property rights. In The Woman in White, the law serves not as a tool for apprehending criminals, but rather enables the victim, Laura, to be taken advantage of by her husband. While previous scholarship has focused on how The Woman in White negotiates questions of identity (Liddle; Peters), female agency and control (Pearl), social norms (Meckier), and sisterly relationships (May), these ideas are best understood through the lens of Collins' critiques. These gendered issues, particularly women's lack of agency as depicted in the novel, are exacerbated by the conditions of inequality that the law creates. Between Hartright and Marian's narratives, Collins interrupts the course of the plot with a 39-page section narrated by the Fairlie family's lawyer, Vincent Gilmore. While this section appears to be dry and of little importance to the novel's sensational and fast-paced plot, Collins uses Gilmore to both explain and critique the legalities of marriage in $19^{\text {th }}$-century 
England. Though Laura is an adult, her marriage and future have been decided for her by other people: her uncle and guardian, Fairlie "looked on his niece's marriage as a settled thing, that her father had sanctioned it, that he sanctioned it himself' (137). Fairlie directs yet another person, Gilmore, a man unrelated to Laura and who barely knows her, to handle the business of her marriage settlement (137). She has no control over the legal circumstances of her own future: the conditions of her future are decided by her father, her uncle, then her lawyer. When Laura hesitates about her impending marriage to Sir Percival, Gilmore asks Marian "what excuse can [Laura] possibly have for changing her mind about a man whom she had virtually accepted for her husband more than two years ago?" to which Marian responds, "in the eyes of law and reason, Mr. Gilmore, no excuse, I dare say" (149). Marian's use of the phrase "in the eyes of law and reason" emphasizes that the perspective of the law is a limited one, one that does not capture the complexities of Laura's situation and feelings. Under the logic of the law, hesitation about one's spouse without concrete evidence is not a good enough excuse for a woman to end an engagement, subtly underscoring the powerlessness of a woman's position in marriage. For the women of The Woman in White, particularly Laura, the law is not a solution to or even an obstacle to crime: it is what puts Laura in a position to be defrauded by her husband in the first place by denying her legal agency within marriage.

This lack of agency is illustrated in the crux of Gilmore's section of the narrative: the creation of the marriage settlement between Laura and Sir Percival. In this section of the novel, it becomes clear that women's well-being, particularly as regards their financial interests, is contingent on the whims of their male guardians and husbands, making their situations precarious and unsafe. A small portion of Laura's money is hers to will as she pleases. Laura attempts to assert some power over her property, asking Gilmore to draw up the settlement in 
such a way that if she dies before Sir Percival, the twenty thousand pounds which are hers outright will go to her sister, Marian (154). However, when Gilmore sends the marriage contract to Sir Percival, he objects to this section of the settlement, requiring that the money will go to him if Laura dies first (162). Stuck at an impasse, Gilmore goes to Laura's uncle, as her guardian, to ask his advice. Fairlie cannot be bothered to support Laura's wish, writing, in a particularly humorous passage, "Was it likely that a young woman of twenty-one would die before a man of forty-five, and die without children? On the other hand, in such a miserable world as this, was it possible to overestimate the value of peace and quietness? If those two heavenly blessings were offered in exchange for such an earthly trifle as a remote chance of twenty thousand pounds, was it not a fair bargain?" (163) Despite the comedic exaggeration of Fairlie's laziness, Collins is launching a serious critique of the law in these passages. In an entirely legal way, Laura has lost all power over even the small part of her property she is allowed to control. Through his careful descriptions of the creation of the marriage contract, Collins makes it clear that a woman's financial security in marriage depends upon the good intentions and attentiveness of her guardian, who, as demonstrated by Laura's uncle Fairlie, should not be taken for granted.

Collins' criticism of marriage laws continues in his depiction of marriage, especially that of Laura and Sir Percival. Their marriage is, of course, motivated by Sir Percival's desire to gain Laura's fortune. He attempts to pressure her into signing over her fortune (276), but when this proves unsuccessful, he hatches a scheme with Count Fosco to fake her death (369). Their unhappy marriage is not an anomaly within The Woman in White; alongside the depiction of Laura and Sir Percival's exploitative marriage, several other characters in the novel critique the institution of marriage. Mrs. Clements, who aids Anne Catherick in passing along crucial 
information about Sir Percival to Marian and Laura, is able to offer this help because she is unmarried, and therefore independent: "if you are ever in trouble, Anne, come to me. I have no husband alive to say me nay, and no children to look after" (104). The usually calm and composed Marian offers an impassioned critique of marriage in conversation with Laura, exclaiming, "Men! They are the enemies of our innocence and our peace - they drag us away from our parents' love and our sisters' friendship - they take us body and soul to themselves, and fasten our helpless lives to theirs as they chain up a dog to his kennel" (196). Even the words of the villainous Count Fosco offer criticisms of the institution of marriage. In his section of the narrative, he offers this explanation for his wife's devotion to him and willingness to aid him in his crimes: "I remember that I am writing in England; I remember that I was married in England — and I ask, if a woman's marriage obligations, in this country, provide for her private opinion of her husband's principles? No! They charge her unreservedly to love, honour, and obey him" (686). All of these passages further underscore the ways in which English marriage laws deny women agency, leaving them open to the potentially villainous intentions of their husbands.

\section{The Law as Complicit in Imperial Crime}

In The Moonstone, Collins' critiques of the British criminal justice system take on larger significance in his depiction of British Imperialism as, morally, a "crime," though it is not recognized as such by British law. The Moonstone has long been read from a postcolonial perspective as a critique of the British Imperial project by scholars such as Reed, Duncan, Roy, and Free. Other scholars, notably Miller and Thomas, have analyzed The Moonstone as a prototypical detective novel, examining the crime at the centre of the novel and the role of its police detectives. When these approaches are combined, the original theft of the Moonstone from 
its homeland can be understood as an Imperialist crime. The first "crime" in The Moonstone, Herncastle's theft of the gemstone from India does not break any British laws. However, despite this, throughout the narrative, Collins treats this theft like a crime, though justice cannot be obtained through traditional legal means. This violent, Imperial theft is the opening scene of the novel. The narrator describes "John Herncastle, with a torch in one hand, and a dagger dripping with blood in the other" (Collins 4). Herncastle is not only a thief, but a murderer as well. By beginning his novel in this way, Collins urges his readers to view the Moonstone, and the Indian Brahmins who later travel to England to retrieve the gemstone, in a specific way. Though it may be tempting to understand them as foreign invaders come to steal from an English family, Collins deliberately resists this interpretation of the Brahmins. He depicts John Herncastle as the originator of the violence that follows the Moonstone, and by extension, the Brahmins as merely recovering what is theirs. As Melissa Free notes, Collins' sympathetic depiction of the Indian Brahmins is an indictment of the Imperial agents who violently stole from them (357). Significantly, when the diamond leaves England for India by boat, it departs at the former site of the East India Company House (Reed 288). This can be read as an un-doing of the theft of colonial resources described in the opening of the novel. In treating this original theft of the Moonstone as a crime of equal weight and importance as its theft from the Verinder home, Collins implicates the entire British colonial project in his understanding of crime. Crime, in The Moonstone, is not defined by what British law forbids, but by those whose property has been stolen and who seek justice.

Similar to The Woman in White, Collins depicts failures of the criminal justice system in The Moonstone, shifting his focus from marriage laws to the police force. The role of the detective in the detective genre is usually to be brilliant, competent, and to restore peace to the 
community by providing the solution to the mystery; Collins' police detectives do no such thing. The first police detective brought in to solve the mystery of the Moonstone's theft proves to be incapable of the task. Seegrave misses a key piece of evidence: the smudged paint on Rachel's bedroom door (84), and incorrectly suspects the Indian Brahmins of the theft (92). After questioning everyone in the household, he seems to have made no discernible progress: "The search over, and no Diamond or sign of a Diamond being found, of course, anywhere, Superintendent Seegrave retired to my little room [.. . ] He and his men had now been hours in the house, and had not advanced us one inch towards a discovery of how the Moonstone had been taken, or of whom we were to suspect as a thief" (89). Seegrave's failures demonstrate the fallibility of the police detective: despite his training and legal mandate to uphold the law, Seegrave is simply not skillful enough to solve such a complex mystery.

Sergeant Cuff, though a more effective investigator than Seegrave, also fails as a detective figure by disrupting and upsetting the community. At first, it seems that the failed detective work of Seegrave is meant to contrast that of Sergeant Cuff, who will seem all the more brilliant and ingenious by comparison and serve as a shining example of police excellence. Cuff inquires about the paint smudge that Seegrave brushed aside and discovers that it must have been smeared at the time the theft occurred (100). However, Cuff's successes end here. He quickly upsets Lady Verinder, who tells Betteredge that "there is something in that police-officer from London which I recoil from-I don't know why. I have a presentiment that he is bringing trouble and misery with him into the house" (105). Lady Verinder's presentiments turn out to be correct, as Cuff proceeds to suspect two innocent people of the crime. At first, he suspects Rosanna Spearman because of her criminal background (109), then turns his mistrust on Rachel Verinder (163), misreading her anger with Franklin Blake and the police officers as guilt (164). By 
suspecting innocent people of the crime, Cuff not only fails to solve the crime, but upsets the already-victimized Verinder household. After his unsuccessful investigations, Sergeant Cuff departs the household on page 179 of the 466-page novel, giving up on the case. He appears once more, briefly, at the close of the narrative, on page 433, when much of the mystery has already been solved, to admit his mistakes: "I own that I made a mess of it. Not the first mess, Mr. Blake, which has distinguished my professional career! It's only in the books that the officers of the detective force are superior to the weakness of making a mistake!" (434). He admits that police officers are flawed, that the figure of the remarkably intelligent, infallible police officer is a work of fiction. Sergeant Cuff's admission of imperfection on its own seems a noble admission of one individual's failings. However, his failure combined with the failure of Superintendent Seegrave and his assisting officers suggests that the failure to investigate is not the fault of an individual, but perhaps of the police institution as a whole, and as such, the legal system in its entirety. In The Moonstone, Collins makes it clear that one cannot count on the police to find justice: not only are they ineffective detectives, but their presence and methods disrupt and upset the community.

\section{Crime and (Extrajudicial) Punishment}

One of Collins' most potent critiques of the criminal justice system in these novels comes not in the form of an explicit criticism, but indirectly, in the absence of criminal sanctions against villains. Fosco and Ablewhite do not face state-sanctioned punishment, but instead are subject to extrajudicial forms of retribution. As Fosco identifies in his monologue, if the problem of unsolved crime could be fixed with smarter police officers, then the mystery of The Woman in White would still remain unsolved; none of the characters in the novel, even those depicted as highly intelligent, are able to match wits with Fosco. Fosco is not defeated because he faces an 
individual who is smarter than him, but because a large community of people come together to defeat him. The fault, then, lies not in the lack of intelligent adversaries to face off against intelligent criminals, but in the inability of the criminal justice system to appropriately apprehend and punish those who deserve it.

Significantly, no criminal charges are laid against Fosco or Sir Percival. Instead, Collins depicts a form of justice that lies outside of the realm of police arrest and imprisonment. While Sir Percival perishes in a fire of his own making (579), Hartright comes to a personal agreement with Fosco, effectively blackmailing him into leaving the country in exchange for his confession. For a moment, Hartright hesitates to allow Fosco to escape the law, but "determine[s] to be guided by the one higher motive of which [he] was certain, the motive of serving the cause of Laura and the cause of Truth" (662). For Hartright, Laura's interests and the pursuit of truth are more important than what the law requires: the possibility of Fosco facing prison and punishment. In return, Fosco asks that he and his wife can leave without interference, as well as the "satisfaction of a gentleman," by which he means a duel with Hartright, at a later date (661). Hartright's acquiescence to the gentleman's duel places him on equal footing with Fosco, implying that their relationship is not that of criminal and detective, but of matched competitors, each operating outside of the legal system. After their agreement is settled, they drink coffee together, and Fosco declares, "we meet as mortal enemies hereafter—let us, like gallant gentlemen, exchange polite attentions in the mean time" (663). Fosco and Hartright do not meet as hero and villain, divided by the law and morality, but as two gentlemen, each pursuing their own interests to the best of their abilities. At the close of the novel, Fosco is not punished in a traditional, legal sense, but is instead executed by extrajudicial agents. Hartright's friend, Pesca, is part of an Italian organization called "The Brotherhood," which Fosco betrayed. One of the 
rules of The Brotherhood is "if [a man's] life inflicts injury on the well-being of his fellow-men, from that moment he forfeits the right, and it is not only no crime but a positive merit to deprive him of it" (644).

Though this code of ethics more closely resembles vigilante justice than English common law, Collins quietly endorses this individualistic form of justice by allowing its adherents to vanquish the novel's villain. When a compatriot of Pesca's overhears Hartright discussing Fosco's crimes, his execution is set in motion. Hartright writes, "the hand that struck him was never traced, and the circumstances under which he was killed were never discovered" (699). The villain of The Woman in White, Count Fosco, faces consequences for his crimes, but these consequences are not sanctioned by the legal system, nor are they discovered by the state.

Instead, Fosco is served a form of justice not originated in or endorsed by the English criminal justice system, but which results in an ending that is depicted as both satisfactory and just by the narrative, both for the villain and for the novel's protagonists who no longer live in fear of his machinations.

Godfrey Ablewhite faces a similarly unconventional punishment in The Moonstone when he is initially cast out by polite society, then later killed by the Indian Brahmins. When his theft of the Moonstone is publicized by the press, he tells the Verinders, "I have become the property of the newspapers" (202). They learn that rumour has spread throughout society that he is a thief, and though the Verinders do not yet believe it, the rest of English aristocratic society does (208). However, excommunication from polite society is the least of the consequences Ablewhite faces; when he attempts to have the Moonstone cut up to make it easier to sell, he is murdered by the Indian Brahmins (445). Collins makes it clear that this execution is not state-sanctioned punishment, but rather, extrajudicial justice. Sergeant Cuff admits that the Indian Brahmins have 
acted in a way that he, an agent of the criminal justice system, cannot trace: "there is here, moral, if not legal, evidence, that the murder was committed by the Indians" (447). Godfrey Ablewhite is never tried in a courtroom or found guilty by a jury, yet the novel's narrators make it clear that he is guilty. The Indian Brahmins, who have committed a murder, also face a form of punishment for their actions, though not one recognized by the English legal system. They escape England and return to India with the diamond, evading apprehension by the police (462), and restore the diamond to its home in Somnauth, where it is worshipped as a sacred object (466). Murthwaite, who witnesses the scene, hears from another spectator that the Brahmins "had forfeited their caste in the service of the god," and as a result, "never more were they to look on each other's faces. Never more were they to rest on their wanderings, from the day which witnessed their separation, to the day which witnessed their death" (465). Rather than subjecting the Brahmins to justice as defined by the English legal system, Collins gives the Indians a punishment appropriate to their crime and significant within the framework of their culture and religious beliefs.

\section{Justice Through Community Cooperation}

In The Woman in White and The Moonstone, justice is not obtained through police or legal intervention, but through community cooperation, as is illustrated in the novel's narrative structure. In the community-narrated format of The Woman in White and The Moonstone, Collins takes the duties of truth-finding, evidence-reading, and deciding who is innocent and who is guilty from the purview of the criminal justice system and places them in the hands of the common person. Truths in both novels are not revealed or defined by a judge, or by external, omniscient narrators, but by the community in which the crime originated. Each narrator is personally involved in the events of the novel and narrates the piece of the plot they witnessed. 
Other critics have identified the ways in which the multiple narrators of The Woman in White and The Moonstone mimic witnesses giving evidence in a legal trial (Miller 162; Free 341). However, there is no question-and-answer format, no listing of facts, no testing of witnesses' truthfulness. These narrators are not simply witnesses giving evidence, but storytellers. Justice in both of these novels is obtained by asking for and listening to others' stories. In The Woman in White, the narrative is told by a succession of characters: not only Walter Hartright, but Marian Halcolmbe, Frederick Fairlie, housekeeper Eliza Michelson, the villainous Count Fosco, Vincent Gilmore, Mrs. Catherick, a doctor, and even a mortician. Gilmore explains that "the plan [Hartright] has adopted for presenting the story to others, in the most truthful and vivid manner, requires that it should be told, at each successive stage in the march of events, by the persons who were directly concerned in those events at the time of their occurrence" (135). The use of the word "vivid" implies something more than the objective utility of a witness statement; in addition to being factual, the narratives that make up The Woman in White are meant to be lively and interesting, to be read not only for their content, but for their compelling narration. Further, Eliza Michelson, Sir Percival's housekeeper, states that her "testimony is wanted in the interests of truth" (397). These narratives do not serve the needs of the law or of the police, but the interests of truth itself.

The solution to the novel's mystery is not found by a singular amateur detective, though Hartright may appear, at first, to fit this mold. The crimes committed against Laura Fairlie are only undone through the cooperation of a community, through their collective narration and truth-giving. As Gilmore states, each narrator tells the part of the story they witnessed, meaning that each narrative is crucial to the coherence of the mystery's solution. Even Count Fosco, the villain, proves necessary to unraveling his own conspiracies - in exchange for his freedom, he 
gives Hartright the contact information for the carriage hire he used on the day he sent Laura to the asylum (661). After Hartright has discovered all the facts of Fosco's fraud, he assembles everyone involved in the case at Limmeridge House, gathering the community together to establish Laura's identity. Once Hartright has told his story, narrating the events of Count Fosco and Sir Percival's villainy, the community, mostly made up of Limmeridge Estate's tenants, literally gather around him and Laura: "the labourers in the village and the boys from the school, assembled on the lawn, caught up the cheering and echoed it back on us. The farmers' wives clustered around Laura and struggled which should be the first to shake hands with her" (694). Laura's inheritance is restored only when the community comes together to witness the telling of her story and recognizes her identity, claiming her as one of their own.

In The Moonstone, Collins again uses the narrative structure he chose for The Woman in White, assembling a large cast of narrators who tell the part of the story they were involved with in turn. Not only are the parts of the story narrated by different characters, but different aspects of the mystery are solved by several people. As Miller writes, "nor is it merely the obvious detective characters $[\ldots]$ who together with their helpers [...] to prosecute the case to a successful conclusion. Necessary information is provided by Rachel (who confesses that she saw Blake take the diamond), Mr. Candy (whose partially recovered memory helps bring his drugging of Blake to light), Limping Lucy (who delivers Rosanna's letter), and even Rosanna herself (whose letter puts Blake in possession of the missing nightgown)" (159). In The Moonstone, the figure of the lone detective is replaced with an entire community cooperating to piece together the mystery. While Bisla argues that in The Moonstone, "the act of having one's story go over to dissemination is akin to having one's body subjected to violation" in the case of Rachel Verinder (198), I argue that storytelling in the novel functions not as a violation, but as 
pathway to justice and truth-finding.

The work that Collins began in The Woman in White, wherein multiple narrators each recount the part of the narrative they witnessed firsthand, is fully realized in The Moonstone, which has even more narrators than The Woman in White and who get more involved in the solving of the crime than do the narrators of The Woman in White. The type of narrative they build together is also significant: it is one more concerned with storytelling than with simply stating facts. Miller argues that "the quasi-legal status of the Prologue extends to the entire novel" (162). However, even the Prologue, the most formal of the narratives, is not addressed to an authority figure, to the police or to a judge, but to family members: "I address these lineswritten in India - to my relatives in England" (1). From its opening, The Moonstone is not a novel concerned with the criminal justice system, but justice as defined by the community. Later, Franklin Blake refers to an earlier section of the novel, calling it "Betteredge's Narrative" (433), as if it is a story or novel, not a piece of evidence or legal document. In fact, much of the novel is concerned with this job of story-making. Franklin Blake gives Betteredge specific instructions about the content of his narrative, though he leaves the form up to Betteredge himself: "the idea is that we should all write the story of the Moonstone in turn - as far as our own personal experience extends, and no farther" (8). Franklin Blake coaxes the reluctant Miss Clack to record her experiences by paying her to do so (192). Blumberg describes Ezra Jennings' role in this process of story-making, writing that "like the biblical Ezra who recorded narratives on scrolls, [Jennings] first transcribes the spoken fragments [of Dr. Candy's narrative], then makes of them an incomplete text, then, finally, a linear narrative" (181). The characters of The Moonstone thus not only participate in solving the mystery, but also in the creation of the mystery's narrative. In what is arguably the climax of the novel, Ezra Jennings and Franklin Blake re-enact the night of 
the theft as "a bold experiment" (384). While Jennings is careful to detail the scientific support for his experiment (385), crucially, the experiment does not take place in isolation in a lab, but in the Verinder home, where the re-enactment is watched by Betteredge, Rachel, Jennings, and Mr. Bruff. They act as an audience for the enacted narrative, simultaneously participating in and witnessing the constructed narrative. The focus of the scene is not how Blake's actions are affected by opium, but on the "plot" being performed; the solution to the mystery of The Moonstone is entangled in the process of storytelling and the creation and re-creation of narratives.

While Collins' many critiques of the criminal justice system in The Woman in White and The Moonstone may seem disheartening, this process of storytelling offers the beginnings of a solution. Just as narration is given over to the common person, so is the decision of who is guilty and who is innocent. The Woman in White and The Moonstone are not addressed to a potential judge or jury, like the popular 1794 proto-detective novel Caleb Williams, but to the reader, whomever they may be. In the opening to The Woman in White, after dismissing the law as a path for recourse, Hartright declares "as the Judge might once have heard it, so the Reader shall hear it now" (1). Sections of The Moonstone, similarly, are addressed, in turn, to John Herncastle's “relatives in England” (1), an unnamed “you” (7), Ezra Jennings' journal (392), Franklin Blake (445), and in the author's Preface, to Wilkie Collins' "readers" (liii). The novels' facts are not presented to a courtroom but to the reader for judgement. Collins sets up the reader as moral arbiter, as an extralegal judge of what is right or wrong, who is criminal and who is innocent. In The Woman in White and The Moonstone, Collins demonstrates the ways in which the English criminal justice system fails to obtain justice, and instead, gives justice over to the regular citizen, the storyteller, the reader. 
The way that Collins engages with the criminal justice system in The Woman in White and The Moonstone is markedly different from other writers of the detective genre who came after him. He alternately critiques the law and its enforcers, replaces it with extrajudicial punishments, and finally, takes its authority over justice, truth, guilt and innocence, and places it in the hands of the people. Certainly not every mystery novel directly involves the police or legal system; Shpayer-Makov distinguishes between different types of "crime fighters," including selfemployed, private detectives, and those who take it on for "altruistic reasons," or "as a way to advance their own private interest or those of family or acquaintances" (165). At first glance, Collins' Walter Hartright and Franklin Blake may even seem to fall into the latter category. However, when seen in the broader context of Collins' critiques of the criminal justice system, his novels seem to fall outside of this framework altogether. The community investigators in The Woman in White and The Moonstone are not especially interested in fighting crime: the goal of characters in each novel is not to end crime, but to protect the well-being of the victims. The punishment of the criminal is not an explicit goal of Walter Hartright or Laura Fairlie, Franklin Blake or Rachel Verinder; rather, they are interested in reacquiring stolen identities, returning stolen property to its rightful owner, and clearing the names of the falsely accused. The Woman in White and The Moonstone depict not only the failures of the law and the police, but a reimagining of "crime" outside of its legal construction, one which asserts the importance of community and values justice over state-sanctioned punishment. Ultimately, The Woman in White and The Moonstone not only depict a flawed criminal justice system and those who must operate without its aid, but a re-imagining of crime altogether. This re-imagination can be seen echoed in today's protest movements that seek to reevaluate the role that police play in our communities and redefine punishment outside of a carceral context. Acknowledging that Collins 
himself, writing over 150 years ago from a position of wealth and privilege, was far-removed from many of the concerns of today's protestors, his novels offer a model of criminality, justice, and the importance of the community outside of the bounds of the criminal justice system. 


\section{Works Cited}

Bisla, S. "The Return of the Author: Privacy, Publication, the Mystery Novel, and The Moonstone.” Boundary 2, vol. 29, no. 1, Mar. 2002, pp. 177-222. Project Muse, doi:10.1215/01903659-29-1-177.

Bradford, Richard. "Origins.” Crime Fiction: A Very Short Introduction, e-book, Oxford University Press, 2015, pp. 2-18.

Collins, Wilkie. The Moonstone, Oxford University Press, 2008.

Collins, Wilkie. The Woman in White, Penguin, 2012.

Duncan, Ian. “The Moonstone, the Victorian Novel, and Imperialist Panic.” Modern Language Quarterly, vol. 55, no. 3, Sept. 1994, pp. 297-319. doi:10.1215/00267929-55-3-297.

Eliot, T.S. "Wilkie Collins and Dickens." Selected Essays, ed. Thomas Stearns, Harcourt, Brace, \& World, 1964, pp. 409-418.

Free, Melissa. “'Dirty Linen': Legacies of Empire in Wilkie Collins's The Moonstone.” Texas Studies in Literature and Language, vol. 48, no. 4, University of Texas Press, 2006, pp. 340-71. JSTOR, https://www.jstor.org/stable/40755470.

Heller, Tamar. "Blank Spaces: Ideological Tensions and the Detective Work of The Moonstone." Dead Secrets, Yale University Press, 1992, pp. 142-63. JSTOR, https://www.jstor.org/stable/j.ctt5hk0xd.10.

Hennelly, Mark M. “Detecting Collins’ Diamond: From Serpentstone to Moonstone.” Nineteenth-Century Fiction, vol. 39, no. 1, 1984, pp. 25-47. JSTOR, doi:10.2307/3044820. Klimaszewski, Melisa. Brief Lives: Wilkie Collins. Hesperus Press, 2011. ProQuest Ebook Central, http://ebookcentral.proquest.com/lib/ryerson/detail.action?docID=800668.Kocak, Deniz. "The Historical Origins of Community Policing in 19th Century Britain and Imperial 
Japan.” Rethinking Community Policing in International Police Reform, vol. 17, 2018, pp.

17-22. JSTOR, https://www.jstor.org/stable/j.ctv6zdc57.10.

Kocak, Deniz. "The Historical Origins of Community Policing in 19th Century Britain and Imperial Japan." Rethinking Community Policing in International Police Reform, vol. 17, Ubiquity Press, 2018, pp. 17-22. JSTOR, https://www.jstor.org/stable/j.ctv6zdc57.10.

Liddle, Dallas. "Wilkie Collins, The Woman in White (1859-60)." Victorian Review, vol. 35, no. 1, 2009, pp. 37-41. JSTOR, https://www.jstor.org/stable/27793695.

Meckier, Jerome. "Wilkie Collins's the Woman in White: Providence against the Evils of Propriety.” Journal of British Studies, vol. 22, no. 1, 1982, pp. 104-26. JSTOR, https://www.jstor.org/stable/175659.

Miller, D. A. "From Roman Policier to Roman-Police: Wilkie Collins's 'The Moonstone.” Novel: A Forum on Fiction, vol. 13, no. 2, 1980, pp. 153-70. JSTOR, doi:10.2307/1345307. Narayan, Niketa G. "The Persistence of the Brahmin Priests in Wilkie Collins's the Moonstone." Victorian Literature and Culture, vol. 45, no. 4, 2017, pp. 783-800. ProQuest, doi:http://dx.doi.org.ezproxy.lib.ryerson.ca/10.1017/S1060150317000213.

Pearl, Sharrona. "Dazed and Abused: Gender and Mesmerism in Wilkie Collins." Victorian Literary Mesmerism, edited by Martin Willis and Catherine Wynne, Rodopi, 2006, pp. 16381.

Peters, Catherine. "The Woman in White: (1859-1860)." The King of Inventors, Princeton University Press, 1991, pp. 205-26. JSTOR, doi:10.2307/j.ctt7zv4s6.16.

Reed, John R. "English Imperialism and the Unacknowledged Crime of 'The Moon-Stone."” Clio, vol. 2, no. 3, June 1973, pp. 281-290. ProQuest, http://search.proquest.com/docview/1300321548/citation/9E8BCCD907A041BCPQ/1. 
Roy, Ashish. “The Fabulous Imperialist Semiotic of Wilkie Collin's The Moonstone.” New Literary History, vol. 24, no. 3, 1993, pp. 657-81. JSTOR, doi:10.2307/469430.

Scaggs, John. "The Police Procedural." Crime Fiction, e-book, Taylor and Francis Group, 2005, pp. 85-104.

Shpayer-Makov, Haia. "Revisiting the Detective Figure in Late Victorian and Edwardian Fiction: A View from the Perspective of Police History." Law, Crime and History, vol. 1, no. 2, 2011, pp. 165-93, https://141.163.201.138/bitstream/handle/10026.1/8867/LCH_V1_ 2_07_Shpayer-Makov.pdf? sequence=4\&isAllowed $=\mathrm{y}$.

Smillie, Rachel Jane. The Lady Vanishes: Women writers and the development of detective fiction. University of Aberdeen, 2014. ProQuest, doi:10079836.

Strahan, Linda. “There's a Hole in the (Inspector) Bucket: The Victorian Police in Fact and Fiction." Clues; Jefferson, vol. 23, no. 3, 2005, pp. 57-62. ProQuest, http://search.proquest.com/pqrl/docview/203671759/abstract/E7DB80C5CF04E21PQ/1.

Thomas, Ronald. "The Moonstone, Detective Fiction and Forensic Science." The Cambridge Companion to Wilkie Collins, edited by Jenny Bourne Taylor, Cambridge University Press, 2006, pp. 65-78. ProQuest, http://search.proquest.com/docview/2137993301/citation/E2FAE97BE3C74531PQ/1. 